\title{
Awareness of national health insurance-covered dental care of adults in Jeju province
}

\author{
Soobin Lee ${ }^{1,2}$, Sung-Joon Kim ${ }^{3,4}$, Chan-Woo Jo ${ }^{3,5}$, and Jaeman Woo $\mathrm{Wo}^{3,5 *}$ \\ ${ }^{1}$ Dental Hygienist, Jeju Medical Check-up Center, Korea Association of Health Promotion, Jeju, Republic of Korea \\ ${ }^{2}$ M.P.H. Student, Graduate School of Public Health and Welfare, Jeju National University, Jeju, Republic of Korea \\ ${ }^{3}$ Professor, Graduate School of Public Health and Welfare, Jeju National University, Jeju, Republic of Korea \\ ${ }^{4}$ Professor, Department of Dentistry, School of Medicine, Jeju National University, Jeju, Republic of Korea \\ ${ }^{5}$ Assistant Professor, Department of Dentistry, School of Medicine, Jeju National University, Jeju, Republic of Korea
}

Advancements in medical care resulted in increase of average longevity. In turn, people have become more concerned about health, oral health, and quality of life. Such change has led to need for systematic and prevention-oriented healthcare service. This study aimed to provide preliminary information on the level of familiarity with national health insurance (NHI) benefits by the general public in order to help make decisions regarding education and advertisement policies. 337 adults who visited Korea Association of Health Promotion health examination center in Jeju were given self-administered surveys regarding personal oral health status, familiarity with NHI-covered procedures, and personal interest in oral health, and the results were analyzed statistically. $83.4 \%$ answered 'Yes,' to awareness of NHI coverage of dental scaling. Most people answered 'Yes' to awareness of the fact that NHI-covered dental scaling begins at 19 years of age, while relatively few people were familiar with NHI-covered denture and dental implant procedures. According to this study, many respondents were still not familiar with the expanded NHI coverage. Especially the younger population lacked information on NHI-covered denture and dental implant, indicating need for public education and advertisements. In order to efficiently advertise and educate, joint effort by the government and medical facilities is recommended. Utilization of social media in addition to the more traditional mass media should be effective in conveying information to the younger population. Age-appropriate education for policy change and coverage expansion regarding NHI-covered denture and dental implant is also advised.

Key Words: Dental scaling; Denture; Dental implant; National health insurance

@) This is an open-access article distributed under the terms of the Creative Commons Attribution Non-Commercial License (http://creativecommons.org/licenses/by-nc/4.0) which permits unrestricted noncommercial use, distribution, and reproduction in any medium, provided the original work is properly cited.

\section{Introduction}

최근 대한민국에서는 경제성장과 더불어 의료기술 발달과 교 육수준의 향상으로 국민의 의료 정보에 관한 관심이 높아지고 있다. 이와 더불어 인구의 노령화가 급속히 진행되고, 건강에 대 한 욕구는 더욱 증가하였으며 개인과 사회는 적극적으로 건강
과 체력을 증진시키고 수명을 연장하는 것에 나날이 높은 관심 을 보이고 있다[1]. 평균 수명의 연장에 따라 구강질환의 발생이 증가하게 되고, 이에 따른 환자의 경제적 부담 및 치료의 고통이 증가되고 있는 실정이다. 이처럼 점차 고령화되는 사회에서 구 강건강이 삶의 질에 미치는 영향 및 구강건강의 중요성에 대한 인식도 날로 높아지고 있다[2].

Received June 28, 2021; Revised [1] August 6, 2021; [2] August 20, 2021; Accepted August 24, 2021

${ }^{*}$ Corresponding author: Jaeman Woo, Department of Dentistry, Jeju National University Hospital, 15 Aran 13-gil, Jeju 63241, Republic of Korea.

Tel: +82-64-717-1843, Fax: +82-64-717-1846, E-mail: jmanwoo@gmail.com

Copyright $\odot 2021$, Oral Biology Research Institute 
세계보건기구는 구강건강이 전신건강과 삶의 질을 유지하는 데 필수 요소임을 시사한 바 있으며, 미디어를 통한 홍보, 치과 병·의원의 증가, 의료보험의 확대적용 등에 힘입어 일반인의 구 강보건에 대한 인식이 과거에 비해 향상되었으나, 최근까지도 구강건강을 소홀히 하는 경향이 관찰되고 있다[3]. 게다가 구강 질환은 진행은 느리나, 한 번 발병하면 자연치유가 힘들고 치료 후에도 발병 전 상태로의 회복은 어렵기 때문에 예방과 조기발 견 및 치료가 매우 중요하다.

2020년 다빈도질병 통계에 의하면 질병별 환자 수와 요양급 여비용총액 모두에서 치은염 및 치주질환이 1 위에 올라있고 치 아우식증이 각각 4위와 8위에 위치해 전 연령에 걸쳐 구강질환 의 유병률이 높으며, 대다수 성인이 연령대가 높아짐에 따라 치 주질환으로 인한 치아 상실을 겪고, 이로 인해 삶의 질이 저하되 고 있어 상실된 치아를 대체하는 보철치료에 대한 요구가 높아 지고 있는 실정이다[4].

현재 대한민국에서는 사회보장체계를 바탕으로 국민의 질병 과 부상에 대한 예방, 진단, 치료, 재활과 출산, 사망 및 건강증 진을 위해 의료급여를 적용하여 국민건강 향상과 사회보장을 증진하려는 목적으로 국민건강보험제도가 실시되고 있으며, 치 과 부문에서도 기존 비급여 진료 항목이었던 치아 홈 메우기, 스 케일링, 만 65세 이상 노인 대상 틀니 및 임플란트 치료, 소아 레 진 치료 등을 급여 대상 적용하여 지속적으로 보험급여 적용 범 위를 늘려가고 있다[1]. 그러나 아직도 많은 국민들이 변경된 건 강보험 혜택을 인지하지 못해 제대로 활용하지 못하는 경우가 있어 치과 건강보험 제도를 보다 효율적으로 알리는 방안과 노 력이 필요하다.

이와 관련된 과거 연구로 치과 건강보험 인식과 영향요인 연 구, 치과치료의 건강보험 급여화에 대한 인식과 관련 요인 연구, 스케일링 건강보험 급여화 인식도 및 만족도 조사, 스케일링 급 여화 이후 소비자 인식 변화와 지역별 시행률에 관한 연구 등이 있었으나, 연구 대상이 치과치료를 목적으로 내원한 의료소비 자로 한정되어있고, 급여화 이후 확대, 변화된 세부사항의 인지 도에 대한 연구도 미미한 수준으로 치과 건강보험 적용 범위가 점차 확대되는 현시점에서 치과 건강보험 적용에 관한 연구는 부족한 실정이다[1,5-7].

본 연구의 목적은 제주도 소재 건강검진센터 성인 내원자를 대상으로 치석제거, 임플란트, 틀니의 건강보험 적용에 대한 인 식도를 파악하고 연구 대상자의 일반적인 특성에 따른 치과 건 강보험적용 인지 여부 및 세부 인지 정도 차이를 분석하는 데 있 다. 이를 통해 향후 치과 건강보험 확대와 제도 개선 등에 활용 할 수 있는 기초 자료를 제공하고, 제주도의 공공의료이용 접근 성을 높이기 위한 정책 개선방안을 제시하여 구강건강 증진에 기여하고자 한다.

\section{Materials and Methods}

2020년 4월 7일부터 4월 14일까지 제주도 소재 건강검진센 터 내원자 중 성인을 대상으로 설문조사를 하였다. 최소 샘플 수 를 측정하기 위해 G*Power ver. 3.1.9.7을 이용하였고 Oneway ANOVA를 이용한 통계연구에 필요한 샘플 수는 159명으 로 예측되었다[8,9]. 임의 선정된 350명이 응답하였으며, 설문 지를 불완전하게 작성한 13 명의 설문을 제외한 총 337 명의 자 료를 최종 분석에 사용하였다. 설문지는 장현희의 2019년 선행 연구에서 사용된 설문지를 현지 실정에 맞게 수정 및 보완을 하 여 총 26문항으로 작성하였다[5] (Supplementary Fig. 1; available online only). 본 연구는 2020년 3월 25일에 제주대학교 생명윤리심의위원회(Institutional Review Board, IRB)의 승인 (승인번호: JJNU-IRB-2020-008)을 받았다.

수집된 자료는 IBM SPSS Statistics ver. 22.0 (IBM Co., Armonk, NY, USA)을 이용하여 통계분석을 시행하였고, 유의수 준은 0.05 로 하였다. 각 문항에 대한 빈도분석과 평균, 표준편 차를 구하였고, 특성에 따라 t-test, chi-squared test, one-way ANOVA 분석과 Scheffe 사후검증을 실시하였다.

\section{Results}

\section{대상자의 일반적 특성}

연구 대상자의 일반적 특성은 Table 1과 같다. 성별은 남자 120 명(35.6\%), 여자 217명(64.4\%)으로 여자가 많았고, 연령에 서는 40대 111명(32.9\%), 50대 이상 87명(25.8\%), 30대 75명 (22.3\%), 20대 64명(19.0\%) 순으로 나타났다. 결혼 여부는 기혼 214 명(63.5\%), 비혼 123 명(36.5\%)으로 기혼이 많았다. 최종학 력은 대학교 재학·졸업 226명(67.1\%), 고등학교 졸업 이하 88 명(26.1\%), 대학원 재학.졸업 23명(6.8\%) 순으로 많았다. 가정 월평균 소득은 200-300만원 미만 111명(32.9\%), 300-400만 원 미만 70명(20.8\%), 500만원 이상 57명(16.9\%), 200만원 미만 54명(16.0\%), 400-500만원 미만 45명(13.4\%)으로 나타났다.

\section{치과 치료의 건강보험 급여화 인식도}

연구 대상자의 치과 건강보험 급여화에 대한 인식 여부는 Table 2와 같다. 조사 결과 치석제거 보험적용 인식 여부에 대 해 '안다' 281명(83.4\%), ‘모른다' 56명(16.6\%), 임플란트 보험 적용 인식 여부에 대해 '안다' 135 명(40.1\%), '모른다' 202명 (59.9\%)으로 나타났으며, 틀니 보험적용 인식 여부에 대해서 '안다' 226명(67.1\%), ‘모른다' 111명(32.9\%)으로 응답하였다. 


\section{치석제거, 임플란트, 틀니의 건강보험 급여화 사업에 대한 세부 인지도}

연구 대상자의 치석제거, 임플란트, 틀니의 건강보험 급여화 사업에 대한 세부 인지도 평가 결과는 Table 3과 같다. 분석 결 과, 급여 치석제거 적용 연령이 만 19세인지를 아는지 여부에 '예' 237명(70.3\%), ‘아니요' 100명(29.7\%), 임플란트 및 틀니 적용 연령이 만 65세인지를 아는지 여부에 ‘예’ 226명(67.1\%), '아니요' 111 명(32.9\%), 급여 임플란트 및 틀니 환자의 건강보 험 본인부담금이 $30 \%$ 인지를 아는지 여부에 ‘예’ 168 명(49.9\%), '아니요' 169명(50.1\%), 급여 치석제거가 매년 1월 1일 갱신

Table 1. Sociodemographic characteristics of respondents

\begin{tabular}{llr}
\hline & Variable & Value $(\mathbf{n}=337)$ \\
\hline Sex & Male & $120(35.6)$ \\
& Female & $217(64.4)$ \\
Age (y) & $20-29$ & $64(19.0)$ \\
& $30-39$ & $75(22.3)$ \\
& $40-49$ & $111(32.9)$ \\
& $\geq 50$ & $87(25.8)$ \\
Marital status & Married & $214(63.5)$ \\
Education & Single & $123(36.5)$ \\
& $\leq$ High school & $88(26.1)$ \\
Monthly household & University & $226(67.1)$ \\
income (10,000 KRW) & $\geq$ Graduate school & $23(6.8)$ \\
& $\leq 199$ & $54(16.0)$ \\
& 200 to $\leq 300$ & $111(32.9)$ \\
& 300 to $\leq 400$ & $70(20.8)$ \\
& 400 to $\leq 500$ & $45(13.4)$ \\
& $\geq 500$ & $57(16.9)$ \\
\hline
\end{tabular}

Values are presented as number (\%).

KRW, Korean won.
되는지를 아는지 여부에 '예' 231명(68.5\%), ‘아니요' 106명 (31.5\%)로 답하였다. 급여 임플란트 및 틀니의 경우 진료 진행 중 병·의원을 옮기는 경우에는 보험이 적용되지 않는다는 것을 아는지 여부에 ‘예' 66명(19.6\%), ‘아니요' 271명(80.4\%), 보험 틀니 제작 후 3개월 이내에 6회 무상으로 보수가 되는지를 아 는지 여부에 '예' 145명(43.0\%), '아니요' 192명(57.0\%)으로 응 답하였고, 보험 부분 틀니 제작 시 지대치의 보철비용이 포함되 지 않는 것을 아는지 여부에 '예' 161 명(47.8\%), '아니요' 176 명(52.2\%)이었으며, 급여 임플란트는 평생 2개만 보험적용이 된다는 것을 아는지 여부에 '예' 98명(29.1\%), ‘아니요' 239명 (70.9\%)으로 나타났다. 마지막으로 보험 임플란트 시술 시 골이 식 등의 부가적인 시술은 비보험 대상인지를 아는지 여부에 '예' 202명(59.9\%), ‘아니요’ 135명(40.1\%)으로 응답하였다.

\section{일반적 특성에 따른 치과치료 급여화 인식 여부 및 세부 인지도 차이}

\section{일반적 특성에 따른 치석제거 급여화 인식 여부 차이}

일반적 특성에 따른 치석제거 급여화 인식도 차이는 다음

Table 2. Awareness of expanded NHI-covered dental procedures

\begin{tabular}{lcc}
\hline \multirow{2}{*}{ Question } & \multicolumn{2}{c}{ Answer $(\mathbf{n}=337)$} \\
\cline { 2 - 3 } & Yes & No \\
\hline $\begin{array}{l}\text { Are you aware of NHI-covered dental } \\
\text { scaling? }\end{array}$ & $281(83.4)$ & $56(16.6)$ \\
$\begin{array}{l}\text { Are you aware of NHI-covered dental } \\
\text { implants? }\end{array}$ & $135(40.1)$ & $202(59.9)$ \\
Are you aware of NHI-covered dentures? & $226(67.1)$ & $111(32.9)$ \\
\hline
\end{tabular}

Values are presented as number (\%).

NHI, national health insurance.

Table 3. Familiarity with NHI-covered scaling, dental implant, and denture

\begin{tabular}{|c|c|c|}
\hline \multirow{2}{*}{ Variable } & \multicolumn{2}{|c|}{ Answer $(n=337)$} \\
\hline & Yes & No \\
\hline 1. Scaling coverage begins at age 19 & $237(70.3)$ & $100(29.7)$ \\
\hline 2. Dental implant and denture coverage begins at age 65 & $226(67.1)$ & $111(32.9)$ \\
\hline 3. Deductible for insurance-covered dental implant and denture is $30 \%$ & $168(49.9)$ & $169(50.1)$ \\
\hline 4. Scaling coverage is renewed every year on January 1 st & $231(68.5)$ & $106(31.5)$ \\
\hline 5. One loses insurance coverage of dental implant and denture treatment when moving to a different dental clinic & $66(19.6)$ & $271(80.4)$ \\
\hline 6. Denture insurance coverage includes 6 sessions for adjustments within the first 3 months & $145(43.0)$ & $192(57.0)$ \\
\hline 7. Surveyed crown (fixed prosthesis) for partial denture is not covered by NHI & $161(47.8)$ & $176(52.2)$ \\
\hline 8. 2 dental implants are covered by NHI in a lifetime & $98(29.1)$ & $239(70.9)$ \\
\hline 9. Adjunct procedures for dental implants are not covered by NHI & $202(59.9)$ & $135(40.1)$ \\
\hline
\end{tabular}

Values are presented as number (\%).

NHI, national health insurance. 
Table 4와 같다. 분석 결과, 성별에서 남자는 '예' 97명(80.8\%), '아니요' 23명(19.2\%), 여자는 '예' 184명(84.8\%), '아니요' 33 명(15.2\%)으로 나타났으며, 통계적으로 유의한 차이는 없었다.

연령대에서 20대는 '예' 44명(68.8\%), '아니요' 20명(31.3\%), 30대는 '예' 64명(85.3\%), '아니요' 11명(14.7\%), 40대는 '예' 98명(88.3\%), '아니요' 13명(11.7\%), 50대 이상은 '예' 75명 (86.2\%), '아니요' 12명(13.8\%)으로 나타났으며 통계적으로 유 의한 차이가 있었다.

결혼 여부에서 기혼은 '예’ 188 명(87.9\%), '아니요' 26명 (12.1\%), 비혼은 '예' 93명(75.6\%), ‘아니요' 30명(24.4\%)으로 유의한 차이가 있었다.

최종학력에서 고등학교 졸업 이하는 '예' 70명(79.5\%), '아니 요' 18 명(20.5\%), 대학교 재학-졸업은 '예’ 188 명(83.2\%), '아 니요’ 38명(16.8\%), 대학원 재학·졸업 이상은 ‘예’ 23명(100\%), '아니요' 0 명(0.0\%)으로 나타났으며, 통계적으로 유의한 차이는 없었다.

소득 수준에서 200만원 이하는 '예' 42명(77.8\%), '아니요' 12 명(22.2\%), 200-300만원 이하는 '예’ 95명(85.6\%), '아니 요' 16명(14.4\%), 300-400만원 이하는 '예' 58명(82.9\%), ‘아니 요' 12 명(17.1\%), 400-500만원 이하는 '예’ 36명(80.0\%), ‘아니 요' 9명(20.0\%), 500만원 이상 '예’ 50명(87.7\%), ‘아니요' 7명 (12.3\%)으로 나타났으며 통계적으로 유의한 차이는 없었다.

\section{일반적 특성에 따른 임플란트 급여화 인식 여부 차이}

연구 대상자의 일반적인 특성에 따른 임플란트 급여화 인 식도 차이는 다음 Table 5 와 같다. 분석 결과, 성별에서 남자 는 '예' 45명(37.5\%), ‘아니요' 75명(62.5\%), 여자는 '예' 90명 (41.5\%), '아니요' 127 명(58.5\%)으로 나타났으며, 통계적으로 유의하지 않았다.

연령에서는 20대에서 '예' 27명(42.2\%), '아니요' 37명 (57.8\%), 30대에서 '예' 29명(38.7\%), '아니요' 46명(61.3\%), 40 대에서 '예' 46명(41.4\%), '아니요' 65명(58.6\%), 50대 이상에 는 '예' 33명(37.9\%), '아니요' 54명(62.1\%)으로 나타났고, 통계 적으로 유의하지 않았다.

결혼 여부에서는 기혼에서 '예’ 83명(38.8\%), '아니요' 131명 (61.2\%), 비혼에서는 '예' 52명(42.3\%), ‘아니요' 71명(57.7\%) 으로 나타났으며, 통계적으로 유의하지 않았다.

학력에서는 고등학교 졸업 이하에서 '예' 35 명(39.8\%), '아니 요' 53명(60.2\%), 대학교 재학.졸업에서 '예' 87명(38.5\%) '아 니요' 139명(61.5\%), 대학원 재학·졸업 이상 ‘예' 13명(56.5\%), ‘아니요' 10 명(43.5\%)으로 나타났다.

소득 정도에서는 200 만원 이하 '예' 25 명(46.3\%), '아니요' 29명(53.7\%), 200-300만원 이하 '예' 46명(41.4\%), '아니요' 65명(58.6\%), 300-400만원 이하 '예' 22명(31.4\%), '아니요' 48명(68.6\%), 400-500만원 이하 '예' 18명(40.0\%), '아니요' 27명(60.0\%), 500만원 이상 ‘예’ 24명(42.1\%), ‘아니요’ 33명

Table 4. Awareness of NHI-covered dental scaling by general characteristics

\begin{tabular}{|c|c|c|c|c|c|}
\hline \multirow{2}{*}{ Variable } & & \multicolumn{2}{|c|}{ Answer $(n=337)$} & \multirow{2}{*}{$\chi^{2}$} & \multirow{2}{*}{$p$-value } \\
\hline & & Yes & No & & \\
\hline \multirow[t]{2}{*}{ Sex } & Male & $97(80.8)$ & $23(19.2)$ & 0.874 & 0.350 \\
\hline & Female & $184(84.8)$ & $33(15.2)$ & & \\
\hline \multirow[t]{4}{*}{ Age $(y)$} & $20-29$ & $44(68.8)$ & $20(31.3)$ & 12.525 & $0.006^{*}$ \\
\hline & $30-39$ & $64(85.3)$ & $11(14.7)$ & & \\
\hline & $40-49$ & $98(88.3)$ & $13(11.7)$ & & \\
\hline & $\geq 50$ & $75(86.2)$ & $12(13.8)$ & & \\
\hline \multirow[t]{2}{*}{ Marital status } & Married & $188(87.9)$ & $26(12.1)$ & 8.446 & $0.004^{*}$ \\
\hline & Single & $93(75.6)$ & $30(24.4)$ & & \\
\hline \multirow[t]{3}{*}{ Education } & $\leq$ High school & $70(79.5)$ & $18(20.5)$ & 5.525 & 0.063 \\
\hline & University & $188(83.2)$ & $38(16.8)$ & & \\
\hline & $\geq$ Graduate school & $23(100)$ & $0(0.00)$ & & \\
\hline \multirow[t]{5}{*}{ Monthly household income (10,000 KRW) } & $\leq 199$ & $42(77.8)$ & $12(22.2)$ & 2.772 & 0.597 \\
\hline & 200 to $\leq 300$ & $95(85.6)$ & $16(14.4)$ & & \\
\hline & 300 to $\leq 400$ & $58(82.9)$ & $12(17.1)$ & & \\
\hline & 400 to $\leq 500$ & $36(80.0)$ & $9(20.0)$ & & \\
\hline & $\geq 500$ & $50(87.7)$ & $7(12.3)$ & & \\
\hline
\end{tabular}

Values are presented as number (\%). $\mathrm{NHI}$, national health insurance. ${ }^{*} p<0.01$. 
Table 5. Awareness of NHI-coverage of dental implants by general characteristics

\begin{tabular}{|c|c|c|c|c|c|}
\hline \multirow{2}{*}{ Variable } & & \multicolumn{2}{|c|}{ Answer $(n=337)$} & \multirow{2}{*}{$\chi^{2}$} & \multirow{2}{*}{$p$-value } \\
\hline & & Yes & No & & \\
\hline \multirow[t]{2}{*}{ Sex } & Male & $45(37.5)$ & $75(62.5)$ & 0.508 & 0.476 \\
\hline & Female & $90(41.5)$ & $127(58.5)$ & & \\
\hline \multirow[t]{4}{*}{ Age $(y)$} & $20-29$ & $27(42.2)$ & $37(57.8)$ & 0.434 & 0.933 \\
\hline & $30-39$ & $29(38.7)$ & $46(61.3)$ & & \\
\hline & $40-49$ & $46(41.4)$ & $65(58.6)$ & & \\
\hline & $\geq 50$ & $33(37.9)$ & $54(62.1)$ & & \\
\hline \multirow[t]{2}{*}{ Marital status } & Married & $83(38.8)$ & $131(61.2)$ & 0.397 & 0.529 \\
\hline & Single & $52(42.3)$ & $71(57.7)$ & & \\
\hline \multirow[t]{3}{*}{ Education } & $\leq$ High school & $35(39.8)$ & $53(60.2)$ & 2.829 & 0.243 \\
\hline & University & $87(38.5)$ & $139(61.5)$ & & \\
\hline & $\geq$ Graduate school & $13(56.5)$ & $10(43.5)$ & & \\
\hline \multirow[t]{5}{*}{ Monthly household income $(10,000 \mathrm{KRW})$} & $\leq 199$ & $25(46.3)$ & $29(53.7)$ & 3.234 & 0.519 \\
\hline & 200 to $\leq 300$ & $46(41.4)$ & $65(58.6)$ & & \\
\hline & 300 to $\leq 400$ & $22(31.4)$ & $48(68.6)$ & & \\
\hline & 400 to $\leq 500$ & $18(40.0)$ & $27(60.0)$ & & \\
\hline & $\geq 500$ & $24(42.1)$ & $33(57.9)$ & & \\
\hline
\end{tabular}

Values are presented as number (\%).

NHI, national health insurance.

Table 6. Awareness of NHI-coverage of dentures by general characteristics

\begin{tabular}{|c|c|c|c|c|c|}
\hline \multirow{2}{*}{ Variable } & & \multicolumn{2}{|c|}{ Answer (n=337) } & \multirow{2}{*}{$\chi^{2}$} & \multirow{2}{*}{$p$-valu } \\
\hline & & Yes & No & & \\
\hline \multirow[t]{2}{*}{ Sex } & Male & $74(61.7)$ & $46(38.3)$ & 2.456 & 0.117 \\
\hline & Female & $152(70.0)$ & $65(30.0)$ & & \\
\hline \multirow[t]{4}{*}{ Age (y) } & $20-29$ & $32(50.0)$ & $32(50.0)$ & 11.597 & $0.009^{\dagger}$ \\
\hline & $30-39$ & $51(68.0)$ & $24(32.0)$ & & \\
\hline & $40-49$ & $83(74.8)$ & $28(25.2)$ & & \\
\hline & $\geq 50$ & $60(69.0)$ & $27(31.0)$ & & \\
\hline \multirow[t]{2}{*}{ Marital status } & Married & $153(71.5)$ & $61(28.5)$ & 5.216 & $0.022^{*}$ \\
\hline & Single & $73(59.3)$ & $50(40.7)$ & & \\
\hline \multirow[t]{3}{*}{ Education } & $\leq$ High school & $61(69.3)$ & $27(30.7)$ & 0.287 & 0.866 \\
\hline & University & $150(66.4)$ & $76(33.6)$ & & \\
\hline & $\geq$ Graduate school & $15(65.2)$ & $8(34.8)$ & & \\
\hline \multirow[t]{5}{*}{ Monthly household income (10,000 KRW) } & $\leq 199$ & $39(72.2)$ & $15(27.8)$ & 6.603 & 0.158 \\
\hline & 200 to $\leq 300$ & $75(67.6)$ & $36(32.4)$ & & \\
\hline & 300 to $\leq 400$ & $52(74.3)$ & $18(25.7)$ & & \\
\hline & 400 to $\leq 500$ & $29(64.4)$ & $16(35.6)$ & & \\
\hline & $\geq 500$ & $31(54.4)$ & $26(45.6)$ & & \\
\hline
\end{tabular}

Values are presented as number (\%).

$\mathrm{NHI}$, national health insurance.

${ }^{*} p<0.05,{ }^{\dagger} p<0.01$.

(57.9\%)으로 유의한 차이는 없었다.

\section{일반적 특성에 따른 틀니 급여화 인식 여부 차이}

연구 대상자 일반적 특성에 따른 틀니 급여화 인식도의 차이
는 다음 Table 6과 같다. 분석 결과, 성별에서 남자 ‘예' 74 명 (61.7\%), ‘아니요' 46명(38.3\%), 여자 ‘예’ 152명(70.0\%), ‘아니 요’ 65명(30.0\%)으로 나타났고, 통계적으로 유의하지 않았다. 연령에서는 20 대에서 '예' 32 명(50.0\%), '아니요' 32 명 
(50.0\%), 30대에서 '예’ 51명(68.0\%), '아니요' 24명(32.0\%), 40 대에서 '예' 83 명(74.8\%), '아니요' 28명(25.2\%), 50대 이상에 서 '예' 60명(69.0\%), ‘아니요' 27명(31.0\%)으로 나타났으며 통 계적으로 유의하였다.

결혼 여부에서는 기혼이 '예' 153 명(71.5\%), '아니요' 61명 (28.5\%), 비혼이 '예' 73 명(59.3\%), '아니요' 50명(40.7\%)으로 나타났고, 통계적으로 유의하였다.

학력에서는 고등학교 졸업 이하에서 '예’ 61명(69.3\%), ‘아니 요' 27명(30.7\%), 대학교 재학·졸업 '예’ 150 명(66.4\%), '아니 요' 76명(33.6\%), 대학원 재학·졸업 이상 '예' 15 명(65.2\%), '아 니요' 8명(34.8\%)으로 나타났고, 통계적으로 유의하지 않았다.

소득 정도에서는 200만원 이하 '예' 39명(72.2\%), '아니요' 15명(27.8\%), 200-300만원 이하 '예’ 75명(67.6\%), '아니요' 36명(32.4\%)이었고, 300-400만원 이하 ‘예' 52명(74.3\%), ‘아 니요' 18명(25.7\%)으로 나타났으며, 400-500만원 이하 ‘예’ 29 명(64.4\%), '아니요' 16명(35.6\%)이었고, 500만원 이상 '예' 31 명(54.4\%), ‘아니요' 26명(45.6\%)으로 통계적으로 유의하지 않 았다.

\section{일반적 특성에 따른 치과치료 건강보험 급여화에 대한 세부 인지도 차이}

일반적 특성에 따른 치석제거, 임플란트, 틀니의 건강보험 급 여화 세부 인지도 수준의 차이는 다음 Table 7과 같다. 분석 결 과, 성별과 결혼 여부, 연령대, 최종학력, 월 소득 중 어느 일반 적 특성에서도 건강보험 급여화 사업 인지도 수준에 차이를 보
이지 않았다.

\section{Discussion}

오늘날 한 국가의 국민 보건 및 의료서비스의 수준은 그 나라 국민의 삶의 질을 나타내는 척도가 되며, 이와 관련된 제도를 발 전시키는 일이 주요 임무가 되고 있다[10]. 우리나라는 국민건 강보험을 시행하며 의료보장성 강화를 위해 국민건강보험 급여 보장 범위와 기준을 점차 확대해 나가고 있다.

치과 치료 서비스 항목에서도 2009년 12월 치아 홈 메우기를 시작으로 완전틀니, 부분틀니, 치석제거, 임플란트 등에 국민건 강보험급여를 제공하여 국민들의 경제적 부담을 덜고 구강 건 강 향상에 기여하고 있다[11].

우리나라 구강질환 중 치아우식증과 치주질환은 발병률이 높 은 편이며, 치아를 발치하게 되는 주 원인이 되고 있다. 치아와 치주조직은 한번 손상 받으면 다시 원래의 상태로 회복이 힘든 비가역적 특성을 가지고 있으며, 특히 질병 소분류별 외래 다빈 도 상병급여 현황에서 치주질환이 다년간 상위권에 머물러 있다.

구강건강은 계속적으로 관리하지 않으면 치아의 상실로 이어 지고, 그로 인해 저작과 발음, 심미적 기능 등의 구강기능을 저 하시키게 되며, 구강 기능을 회복시키기 위해 보철치료를 해야 할 경우 경제적으로 큰 부담이 따른다[1,12]. 그러나 아직도 많 은 사람들이 예방적 치과치료의 필요성과 치과 건강보험 급여 화 제도의 인식이 부족하여 혜택을 효율적으로 보장받지 못하 고 있다.

Table 7. Familiarity with NHI-covered dental procedure details by general characteristics $(n=337)$

\begin{tabular}{|c|c|c|c|c|c|c|}
\hline \multirow{2}{*}{ Variable } & & \multicolumn{3}{|c|}{ Familiarity } & \multirow{2}{*}{$t / F(p)$} & \multirow{2}{*}{ Scheffe } \\
\hline & & Number & Mean & SD & & \\
\hline \multirow[t]{2}{*}{ Sex } & Male & 120 & 4.43 & 2.37 & $-0.719(0.473)$ & \\
\hline & Female & 217 & 4.62 & 2.18 & & \\
\hline \multirow[t]{2}{*}{ Marriage } & Married & 214 & 4.63 & 2.22 & $0.798(0.425)$ & \\
\hline & Single & 123 & 4.42 & 2.31 & & \\
\hline \multirow[t]{4}{*}{ Age $(y)$} & $20-29$ & 64 & 4.17 & 2.45 & $1.563(0.198)$ & N/A \\
\hline & $30-39$ & 75 & 4.41 & 2.05 & & \\
\hline & $40-49$ & 111 & 4.89 & 2.01 & & \\
\hline & $\geq 50$ & 87 & 4.52 & 2.51 & & \\
\hline \multirow[t]{3}{*}{ Education } & $\leq$ High school & 88 & 4.39 & 2.35 & $0.362(0.696)$ & N/A \\
\hline & University & 226 & 4.60 & 2.20 & & \\
\hline & $\geq$ Graduate school & 23 & 4.74 & 2.47 & & \\
\hline \multirow[t]{5}{*}{ Monthly household income (10,000 KRW) } & $\leq 199$ & 54 & 4.69 & 2.07 & $0.831(0.506)$ & N/A \\
\hline & 200 to $\leq 300$ & 111 & 4.73 & 2.22 & & \\
\hline & 300 to $\leq 400$ & 70 & 4.43 & 2.46 & & \\
\hline & 400 to $\leq 500$ & 45 & 4.69 & 2.23 & & \\
\hline & $\geq 500$ & 57 & 4.12 & 2.22 & & \\
\hline
\end{tabular}

NHI, national health insurance; SD, standard deviation; N/A, not applicable. 
이에 본 연구는 제주도 소재 건강검진센터에 내원한 성인 337 명을 대상으로 치석제거, 임플란트, 틀니의 건강보험 적용 인지 여부와 세부 인식정도를 파악하고 분석하여 향후 치과 건 강보험 확대와 제도 개선에 활용될 수 있는 자료를 제공하고자 하였다.

치과 건강보험 급여화 인식도에 관한 문항 중 예방적 치석제 거 보험적용 여부에서 '안다'로 응답한 대상자가 281명(83.4\%) 으로 높게 나타났고, 치과 건강보험관련 홍보 경로에서 '매스컴 을 통해’ 64명(19.9\%), ‘주변에서 알려줘서(가족, 지인 등)' 48 명(14.2\%) 순으로 높게 나타났다. 이는 Ha [7]의 연구에서 스케 일링 급여화 사업에 대해 알고 있다는 응답(62.4\%)과 유사하였 고, 홍보 노출 경로는 매스컴이 $39.2 \%$, 지인이 $30.7 \%$ 로 조사된 결과와 비슷하였다.

치석제거 급여화에 대한 인식도는 대체로 높게 조사되어 기 존 연구와 비슷한 결과를 보였다[5-7]. 본 연구에서 급여 치석제 거 적용 연령이 19세라는 것을 아는지 여부에 대해 '예' 237명 (70.3\%), '아니요' 100명(29.7\%), 급여 치석제거는 매년 1년 한 번 1월에 갱신된다는 것을 아는지 여부에 '예' 231명(68.5\%), '아니요' 106명(31.5\%)으로 가장 높은 세부 인지 수준을 보였 다. 치과 건강보험 확대 항목 중 치석제거는 시행 기간이 7년이 지남에 따라 급여 적용 여부 인지도가 높아졌을 뿐만 아니라, 성인의 전 연령 대상 항목이기 때문에 성공적으로 예방적 치과 의료서비스 접근성을 높였다고 생각된다. 그러나 국민건강증 진종합계획에 따르면 2015년 성인의 급여 치석제거 이용률은 $16.6 \%$ 으로 비교적 낮은 수진율에 머물고 있다[13].

치주질환은 성인에서 흔하게 나타나는 만성 질환으로 정기 검진과 치석제거술을 통해 예방이 가능한 질환임에도 불구하고 예방적 처치의 중요성에 대한 인식이 낮아 치주질환 이환율은 높은 편이다[6]. 따라서 정기검진과 급여 치석제거술에 대한 적 극적인 홍보와 교육을 통해 국민의 구강건강 증진 효과를 기대 할 수 있을 것으로 예측된다.

치과건강보험 급여 세부인지수준 평가에서 치석제거술 인지 여부 항목을 제외하고 대부분 평가점수가 낮게 나타났다. 이 역 시 기존 연구와 비슷한 결과로 치과 건강보험의 급여화 확대 사 실에 대한 홍보도 중요하지만 적용 기준에 대한 세부사항을 효 과적으로 전달할 수 있는 방안도 필요하다고 사료된다[14,15].

전반적으로 급여 임플란트에 대한 인지도는 낮게 조사되었 고, 이는 Jang [5], Oh 등[16]의 결과와 유사하였다. 이러한 결과 는 임플란트, 틀니의 보험적용 연령이 확대되고 본인부담금이 경감되는 등 변경된 세부사항의 정보 전달이 미흡한 결과라고 생각한다. 병·의원이나 보건소, 노인 복지회관, 요양 시설 등 65 세 이상 노인층의 접근이 잦은 환경에 특화된 보건교육자료 보 급과 치과전문가의 상담이 적절하게 이루어져야 할 것으로 생
각된다.

또한, 기존 국민 구강건강실태조사는 모든 연령층을 포함하 여 3년 주기로 5회까지 시행되었으나, 2012년 시행 이후 2015 년부터는 아동 구강 건강실태 조사로 변경되어 연령층별 구강 보건 사업 개발을 위한 기초적인 조사가 부족 할 뿐만 아니라 지 역적 특색에 맞는 세분화 사업도 힘들 것이라 예상된다.

본 연구의 제한점으로는 제주도에 거주하는 일반 성인을 대 상을 조사하고자 하였으나, 건강검진 센터 내원객 특성상 표본 추출이 공단 건강검진 해당 연령층인 만 40 대 이상의 지역가입 자, 직장가입자가 많아 일반 성인의 표본이라 하기에는 부족함 이 있으므로, 추후 연령층을 고려한 표본 추출과 연령 특화된 세 부 설문 문항을 구성하여 치과 건강보험 급여화 시행 및 확대 이 후 국민들의 인식과 인지도, 요구도와 만족도를 조사할 필요가 있다.

구강질환이 진행된 후의 치료에 집중된 제도적 장치보다 예 방과 조기진단 중심의 제도적 발전이 이루어진다면 국비절감 뿐 아니라 국민 구강건강 증진에도 도움이 될 것이라 생각된다. 현재 전 세계가 코로나19를 겪으며 국가 차원의 질병관리능력 의 중요성을 절감하고 있고, 포스트-코로나 시대에는 근본적이 며 장기적인 국가 단위 건강보험과 질병관리 체계의 변화가 필 요할 것으로 보인다. 또한, 이러한 제도의 변화는 비단 전염병 만이 아니라 구강질병을 포함한 전방위적인 변화로 이어지리라 생각한다.

\section{Acknowledgements}

The authors declare that the submitted manuscript is an original contribution not previously published or under consideration for publication elsewhere.

\section{Conflicts of Interest}

The authors declare that they have no competing interests.

\section{ORCID}

\author{
Soobin Lee \\ https://orcid.org/0000-0002-3577-1580 \\ Sung-Joon Kim \\ https://orcid.org/0000-0003-0603-4036 \\ Chan-Woo Jo \\ https://orcid.org/0000-0003-4777-0080
}


Jaeman Woo

https://orcid.org/0000-0001-7209-186X

\section{References}

1. Lee KH, Lee SB, Jung EY, Jo EB, Jung ES. Factors influencing awareness of dental health insurance among adults. J Korean Soc Dent Hyg 2018;18:771-783. doi: 10.13065/ jksdh.20180066.

2. Sung SI. A study on the utilization of national health insurance care benefit for the elderly denture and dental implants [dissertation]. Nonsan: Konyang University; 2020.

3. Kassebaum NJ, Bernabé E, Dahiya M, Bhandari B, Murray $C J$, Marcenes W. Global burden of untreated caries: a systematic review and metaregression. J Dent Res 2015;94:650-658. doi: 10.1177/0022034515573272.

4. Frequently diagnosed disease statistics [Internet]. Wonju: Health Insurance Review \& Assessment Service [cited 2021 Aug 18]. Available from: http://opendata.hira.or.kr.

5. Jang HH. Cognition and related factors about national health insurance benefits of teeth scaling, implants and dentures [Thesis]. Daegu: Kyungpook National University; 2019.

6. Lee BG. A study of the dental-care customer's recognition and satisfaction after 2-year national health insurance of dental scaling [Thesis]. Busan: Dong-Eui University; 2016.

7. Ha MY. A study on the changes in consumers' awareness and the rate of scaling in each region after its coverage by the national health insurance scheme [Thesis]. Yongin: Dankook University; 2015.

8. Faul F, Erdfelder E, Lang AG, Buchner A. G*Power 3: a flexible statistical power analysis program for the social, behavioral, and biomedical sciences. Behav Res Methods 2007;39:175-191. doi: 10.3758/bf03193146.

9. Faul F, Erdfelder E, Buchner A, Lang AG. Statistical power analyses using $G^{*}$ Power 3.1: tests for correlation and regression analyses. Behav Res Methods 2009;41:1149-1160. doi: 10.3758/BRM.41.4.1149.

10. Hwang YS, Jung JY, Kim KM, Hwang SH, Han JY, Park $\mathrm{KH}$. Changing recognition and service status for the health insurance benefit scaling. J Korean Dent Hyg Sci 2015;17:195-207.

11. Kim HN, Kim CB, Kim NH. Changes in factors on unmet dental scaling rate according to the National Health Insurance coverage. J Korean Soc Dent Hyg 2017;17:539-551. doi: $10.13065 / \mathrm{jksdh} .2017 .17 .03 .539$.

12. Choi YE. A study on the national health insurance coverage extension implant and denture for elderly people [Thesis]. Nonsan: Konyang University; 2017.

13. The first public oral health plan- outcome assessment [Internet]. Sejong: Ministry of Health and Welfare; 2017 Jun 8 [cited 2021 Aug 18]. Available from: http://mohw.go.kr.

14. Cho HR. A study on the awareness about 'national health insurance coverage of denture, implant of elderly people': comparison of the difference between Seoul metropolis and locality [Thesis]. Yongin: Dankook University; 2015.

15. Lee KH, Son JY, Lee HO, Shin SH, Jeon HJ, You HJ, Mun $\mathrm{SH}, \mathrm{Kim}$ JY. Factors affecting the recognition about scaling after health insurance benefit business for scaling by national health insurance corporation. J Korean Soc Dent Hyg 2017;17:355-368. doi: 10.13065/jksdh.2017.17.03.355.

16. Oh SH, Lee YJ, Lee YJ, Lee JM, Lee JH, Kim SH. A study on the recognition about national health insurance coverage of denture, implant of elderly people. J Dent Hyg Sci 2014;14:502-509. doi: 10.17135/jdhs.2014.14.4.502 